\title{
ДО ПИТАННЯ ЗАХВОРЮВАНОСТІ НА ІНФЕКЦІЙНІ ХВОРОБИ ОКРЕМОГО КОНТИНГЕНТУ НАСЕЛЕННЯ, ЩО ОБСЛУГОВУЄТЬСЯ МЕДИЧНИМИ ЗАКЛАДАМИ ДЕРЖАВНОГО УПРАВЛІННЯ СПРАВАМИ
}

\author{
ДУ «Український інститут стратегічних досліджень МОЗ України», м. Київ \\ Санітарно-епідеміологічна станція Державного управління справами, м. Київ, Україна
}

\begin{abstract}
Мета: вивчити та проаналізувати динаміку захворюваності на інфекційні хвороби окремого контингенту населення, яке обслуговується у закладах охорони здоров'я Державного управління справами (ДУС).

Матеріали і методи. У ході виконання роботи використано статистичний метод дослідження. Статистичній обробці підлягали форми статистичної звітності за 2012-2013 рр.

Результати. За досліджуваний період встановлено зниження показника захворюваності за наступними нозологіями: краснуха $(16,86)$, скарлатина $(13,49)$, кашлюк $(8,43)$, харчова токсикоінфекція $(7,37)$; та підвищення показника захворюваності за наступними нозологіями: гострі респіраторні вірусні інфекції $(6833,45)$, грип $(230,83)$, вітряна віспа $(83,02)$, ангіна $(46,08)$.

Висновки. Встановлено спорадичний характер захворюваності на інфекційні хвороби населення, яке обслуговується ЗОЗ ДУС. Робота санітарно-епідеміологічної станції була спрямована на проведення профілактичних заходів щодо інфекційної захворюваності спеціального контингенту населення.
\end{abstract}

КЛЮЧОВІ СЛОВА: інфекційні хвороби, захворюваність, спеціальний контингент населення, державне управління справами.

Стан здоров'я людей займає особливе місце у системі цінностей цивілізованої країни. Здоров'я населення країни відображає їі соціальноекономічне, екологічне, демографічне і санітарногігієнічне благополуччя, є одним із соціальних індикаторів суспільного прогресу, важливим чинником, який впливає на якість та ефективність трудових ресурсів [1-3].

Вивчення тенденцій захворюваності та поширеності хвороб серед населення є однією з важливих складових стратегічного планування медичної галузі [4].

У 2013 р. порівняно з 2009 р. серед дорослого населення України спостерігалось зростання як рівнів захворюваності, так і питомої ваги захворюваності за 13 із 16 класів хвороб, у тому числі на деякі інфекційні та паразитарні хвороби з 3,63\% до 3,85\% [5;6].

Мета роботи: вивчити та проаналізувати динаміку захворюваності на інфекційні хвороби окремого контингенту населення, яке обслуговується у закладах охорони здоров'я Державного управління справами (ДУС).

Матеріали і методи. У ході виконання роботи використано статистичний метод дослідження. Статистичній обробці підлягали наступні форми статистичної звітності за 2012-2013 рр: оФ. № 1 "Звіт про окремі інфекції і паразитарні захворювання”; оф. № 2 „Звіт про окремі інфекції

(С) Л.В. Крохмалюк, 2014 і паразитарні захворювання"; оф. № 4 "Звіт про результати обстеження крові на ВІЛ-інфекцію"; оФ. № 70 "Звіт про профілактичні щеплення"; оФ. № 71 "Звіт про профілактичні щеплення, які проводяться за епідемічними показаннями"; оФ. № 6 „Звіт про контингент дітей і підлітків, яким здійснено щеплення проти інфекційних захворювань". Отримані результати підлягали статистичній обробці з використанням програм Statistika 6.0 та MS Excel.

Результати дослідження та їх обговорення. Серед населення, що обслуговується медичними закладами ДУС, інфекційна захворюваність мала спорадичний характер. Не реєструвалось спалахів гострих кишкових захворювань, випадків захворювань на черевний тиф, паратифи, геморагічні лихоманки, менінгококову інфекцію, епідемічний паротит, краснуху, кашлюк, лептоспіроз, туберкульоз, коросту, педикульоз, малярію.

Інфекційна захворюваність за 2013 рік порівняно з 2012 роком наведена у таблиці.

3 таблиці видно, що в 2013 р. порівняно з 2012 р. зареєстровано зниження показника захворюваності населення, яке обслуговується 303 ДУС за 10 (40,0\%) нозологіями. При цьому найвищі рівні зниження показника зареєстровано за наступними нозологіями: краснуха $(16,86)$, скарлатина $(13,49)$, кашлюк $(8,43)$, харчова токсикоінфекція $(7,37)$. Зареєстровано достовірне зниження показника укусів тварин - 33,59 на 100000 відповідного населення. 
Таблиця. Динаміка інфекційної захворюваності серед населення, яке обслуговується медичними закладами Державного управління справами (2012-2013 рр.)

\begin{tabular}{|c|c|c|c|c|c|}
\hline \multirow{2}{*}{$\begin{array}{c}\text { Назва } \\
\text { захворювання }\end{array}$} & \multicolumn{2}{|c|}{$2013 \mathrm{p}}$. & \multicolumn{2}{|c|}{$2012 \mathrm{p}}$. & \multirow{2}{*}{$\begin{array}{c}\text { Зміна } \\
\text { показника }\end{array}$} \\
\hline & абс. & $\begin{array}{c}\text { на } \\
100 \text { тис. }\end{array}$ & абс. & $\begin{array}{c}\text { на } \\
100 \text { тис. }\end{array}$ & \\
\hline Дизентерія & 1 & 2,95 & 3 & 8,43 & $-5,48$ \\
\hline Гострий ентероколіт & 42 & 123,92 & 41 & 115,22 & $+8,7$ \\
\hline Харчова токсикоінфекція & 25 & 73,76 & 29 & 81,49 & $-7,73$ \\
\hline Сальмонельоз & 10 & 29,50 & 11 & 30,91 & $-1,41$ \\
\hline Сума ГКЗ & 78 & 230,14 & 84 & 236,06 & $-5,92$ \\
\hline Вірусний гепатит & 15 & 44,26 & 9 & 25,29 & $+18,97$ \\
\hline у т.ч. вір. гепатит «В» & 2 & 5,9 & - & - & $+5,9$ \\
\hline у т.ч. вір. гепатит «ТT» & 1 & 2,95 & - & - & $+2,95$ \\
\hline у т. ч. хронічні вірусні гепатити: & 12 & 35,41 & 9 & 25,29 & $+10,12$ \\
\hline $\begin{array}{l}\text { у т.ч. хронічний вірусний гепатит «В» } \\
\text { (вперше виявлений) }\end{array}$ & 2 & 5,9 & 2 & 5,62 & $+0,28$ \\
\hline $\begin{array}{l}\text { у т.ч. хронічний вірусний гепатит «С» } \\
\text { (вперше виявлений) }\end{array}$ & 10 & 29,50 & 7 & 19,67 & $+9,83$ \\
\hline Вітряна віспа & 71 & 209,48 & 45 & 126,46 & $+83,02$ \\
\hline Краснуха & - & - & 6 & 16,86 & $-16,86$ \\
\hline Дифтерія & 1 & 2,95 & - & - & $+2,95$ \\
\hline Інфекційний мононуклеоз & 1 & 2,95 & 1 & 2,81 & $+0,14$ \\
\hline Kip & 1 & 2,95 & 2 & 5,62 & $-2,67$ \\
\hline Скарлатина & 4 & 11,80 & 9 & 25,29 & $-13,49$ \\
\hline Кашлюк & - & - & 3 & 8,43 & $-8,43$ \\
\hline Сума повітряно-краплинних інфекцій & 78 & 230,14 & 66 & 185,47 & $+44,67$ \\
\hline Укуси тваринами & 41 & 120,97 & 55 & 154,56 & $-33,59$ \\
\hline Малярія вперше діагностована & - & - & 1 & 2,81 & $-2,81$ \\
\hline Хвороба Лайма & 14 & 41,31 & 7 & 19,67 & $+21,64$ \\
\hline Ангіна & 48 & 141,62 & 34 & 95,54 & $+46,08$ \\
\hline Грип & 143 & 421,92 & 68 & 191,09 & $+230,83$ \\
\hline Гострі респіраторні вірусні інфекції & 5925 & 17481,49 & 3789 & 10648,04 & $+6833,45$ \\
\hline
\end{tabular}

За роки дослідження зареєстровано підвищення показника захворюваності населення, яке обслуговується $3 О 3$ ДУС, за 15 (60,0\%) нозологіями. При цьому найвищі рівні зниження показника зареєстровано за наступними нозологіями: гострі респіраторні вірусні інфекції $(6833,45)$, грип $(230,83)$, вітряна віспа $(83,02)$, ангіна $(46,08)$. Усі ці хвороби належать до групи респіраторних вірусних інфекцій.

За даними ВООЗ, гострі кишкові інфекції (ГКІ) у загальній структурі інфекційної захворюваності в світі займають друге місце після гострих респіраторних вірусних інфекцій. Вони можуть не тільки призвести до розвитку у частини хворих тяжкого стану, але й становлять безпосередню загрозу життю пацієнта. Щороку в світі від ГКІ помирає 5-10 млн осіб. Серед інфекційних хвороб, що реєструються в Україні, ГKІ залишаються надзвичайно актуальними.
Захворюваність ГKI серед населення, яке обслуговується медичними закладами ДУС, за 2013 р. зменшилася порівняно з 2012 р. на 6 випадків, у тому числі на дизентерії - на 2 вип., сальмонельози - на 1 вип., харчову токсикоінфекцію - на 4 вип. Кількість гострих гастроентероколітів збільшилася на 1 випадок.

Захворюваність мала спорадичний характер. У 2013 р. зареєстровано 78 випадків ГКІ проти 84 у 2012 р., у тому числі: 1 вип. гострої дизентерії проти 3 вип. у 2012 р.; 42 вип. гострих гастроентероколітів проти 41 вип. у 2012 р.; 25 вип. харчових токсикоінфекцій проти 29 вип. у 2012 р.; 10 випадків сальмонельозів, проти 11 вип. у 2012 р.

Інтенсивний показник захворюваності ГKI за 2013 рік на 100 тис. населення становить 230,14 проти 236,06 в 2012 році.

За медичною допомогою усі хворі на гострі кишкові захворювання (ГКЗ) звернулися в перші три дні захворювання (100\%). 
Відбір матеріалу на бактеріологічні дослідження проведено у кожному випадку реєстрації ГКЗ своєчасно, в перший день встановлення первинного діагнозу, крім випадку, коли пацієнт відмовився від бактеріологічного обстеження (діагноз: «гострий гастроентероколіт»).

Лабораторне підтвердження при встановленні діагнозів «сальмонельоз», мали місце у 100\% випадків; діагнозу «дизентерія» - 100\%; діагнозу «гострий гастроентероколіт» - 4,77\%; діагнозу «харчова токсикоінфекція» - 88,0\%.

Ймовірні фактори передачі інфекції встановлено у 97,44\%: 47,44\% - м'ясопродукти; 10,26\% молочні продукти; 6,41\% - риба і рибопродукти; 3,85\% - морепродукти; 7,69\% - фрукти та овочі; 3,85\% - яйця; 5,13\% - різноманітні салати; 2,56\% - кондитерські та кулінарні вироби.

Із загальної кількості хворих на ГКІ госпіталізовано 12,82\%. У вогнищах ГКІ реєструвалися спорадичні випадки захворювань.

Усі випадки ГКЗ були спорадичними, крім 4 випадків (2 вип. гострих гастроентероколітів, 2 вип. харчової токикоінфекцій), що були зареєстровані у членів однієї сім'ї (мати, батько, дві дитини).

Слід зазначити, що випадки ГКЗ не були пов'язані з вживанням їжі у закладах громадського харчування, які належать до структури ДУС, Кабінету Міністрів України, Верховної Ради України.

З метою підвищення санітарно-гігієнічної освіти з питань профілактики ГКІ у лікувально-профілактичні і санаторно-курортні заклади Управління охорони здоров'я та медичного забезпечення направлено інформаційний лист «Про епідемічну ситуацію з гострих кишкових захворювань» (вих. № 08/03-2/271 від 26.07.2013 р.).

За 2013 рік зареєстровано 10 випадків захворювань на сальмонельоз, інтенсивний показник на 100 тис. населення склав 29,50 проти 11 випадків у 2012 році, інтенсивний показник - 30,91. Захворюваність мала спорадичний характер.

Із загальної кількості хворих на сальмонельоз: за статтю: 4 чоловіка (40\%) і 6 жінок (60\%); за віком: - до 30 років - 1; від 40 до 49 років - 1; від 50 до 59 років - 2; від 60 до 69 років - 4; понад 70 років - 2; працюючих - 4 (40\%), непрацюючих - 6 (60\%). Звернулись по медичну допомогу: в перші 24 години захворювання - 6 осіб; 24-48 годин - 4 особи.

По медичну допомогу у відділення швидкої медичної допомоги ДНУ «НПЦ ПКМ» звернулись 7 хворих, в 1 вип. було звернення на амбулаторний прийом, у 2 вип. - самозвернення до лікарні.

Лікувалися вдома під наглядом лікаря-інфекціоніста і терапевта 6 (60\%) осіб, 4 (40\%) хворих пройшли курс стаціонарного лікування: в інфекційному відділенні міської клінічної лікарні № 9 - 1 особа; у клінічній лікарні «Феофанія» - 3 особи.
Діагноз „сальмонельоз” підтверджено лабораторно в 100\% випадків. Джерело збудника інфекції не встановлено.

Ймовірні фактори передачі встановлені в усіх випадках: м'ясні продукти харчування - 2 вип.; яйця - 3 вип.; молочні продукти - 2 вип.; морепродукти - 1 вип.; кондитерські вироби - 1 вип.; кавун - 1 випадок.

Протиепідемічні заходи були проведені у кожному вогнищі своєчасно та у повному обсязі.

У 2013 р. серед населення, яке обслуговується медичними закладами ДУС, зареєстровано 42 випадки захворювання на гастроентероколіти, що на 1 вип. більше, ніж у 2012 р., коли зареєстровано 41 вип.; інтенсивний показник склав 123,92 на 100 тис. населення проти 115,22 на 100 тис. населення у 2012 р.

Із загальної кількості хворих на гастроентероколіти: за статтю: 21 чоловік (50\%), 21 жінка (50\%); за віком: до 30 р. - 10 осіб; від 30 до 39 р. 6 осіб; від 40 до 49 - 4 особи; від 50 до 59 9 осіб; від 60 до 69 років - 6 осіб; понад 70 років - 7 осіб; працюючих - 19 осіб (45,24\%), непрацюючих - 23 особи (54,76\%).

Усі хворі звернулись по медичну допомогу в перші два дні від початку захворювання до відділення швидкої медичної допомоги ДНУ «НПЦ ПКМ».

Відбір матеріалу на бактеріологічні дослідження проведено в кожному випадку реєстрації гострого гастроентероколіту, своєчасно, в перший день встановлення первинного діагнозу, крім одного випадку, коли пацієнт відмовився від бактеріологічного обстеження.

В інфекційні відділення клінічних лікарень було госпіталізовано 3 (7,15\%) хворих: Олександрівська лікарня - 2 особи; Клінічна лікарня «Феофанія» - 1 особа.

Ймовірні фактори передачі встановлені в 41 вип. (97,62\%): молочні продукти - 5 вип.; м'ясні продукти - 23 вип.; яйця - 2 вип.; рибні продукти - 4 вип.; різноманітні салати - 3 вип.; овочі, фрукти - 4 вип.

Протиепідемічні заходи були проведені в кожному вогнищі своєчасно та у повному обсязі.

У 2013 р. серед населення, яке обслуговується медичними закладами ДУС, зареєстровано 25 випадків харчових токсикоінфекцій (XTI), інтенсивний показник становив 73,76 на 100 тис. населення проти 29 випадків у 2012 році, показник 81,49 . Захворюваність зменшилася на 4 випадки, мала спорадичний характер.

Із загальної кількості хворих на XTI: за статтю: 14 (56\%) чоловіків, 11 (44\%) жінок; за віком: до 30 р. - 3 осіб; від 30 до 39 р. - 5 осіб; від 40 до 49 р. - 3 особи; від 50 до 59 - 4 особи; від 60 до 69 5 осіб; понад 70 років - 5 осіб; працюючих 14 осіб (56 \%), непрацюючих - 11 осіб (44\%). 
Усі хворі звернулись по медичну допомогу в перші два дні від початку захворювання. До відділення швидкої медичної допомоги ДНУ «НПЦ ПКМ» звернулися 24 особи, на амбулаторний прийом до кабінету інфекційних захворювань звернулася одна особа.

Відбір матеріалу на бактеріологічні дослідження проведено в кожному випадку реєстрації XTI, своєчасно, в перший день встановлення первинного діагнозу.

В інфекційні відділення міських клінічних лікарень було госпіталізовано 2 (8,0\%) хворих: Олександрівська лікарня - 1 випадок; міська клінічна лікарня № 4 - 1 випадок.

Ймвірні фактори передачі встановлено у 24 випадках: м'ясні продукти харчування - 12 вип.; рибні продукти - 3 вип.; морепродукти - 2 вип.; молочні продукти - 1 вип.; різноманітні салати 3 вип.; кондитерські вироби з кремом - 1 вип.; фрукти, овочі - 2 випадки.

Робота епідеміологічного відділу санітарноепідеміологічної станції ДУС була спрямована на покращення санітарно-протиепідемічного стану закладів, виконання протиепідемічного режиму, проведення заходів з профілактики інфекційної захворюваності серед населення, яке обслуговується 303 Управління охорони здоров'я та медичного забезпечення ДУс. Так, було проведено 51 обстеження лікувально-профілактичних, санаторно- курортних, дитячих дошкільних закладів з питань виконання протиепідемічного режиму і впровадження профілактичних заходів, 3 них планово - 46, за епідпоказаннями - 5 (2012 р. - 53 обстеження, з них планово - 45, за епідпоказаннями - 8). Під час перевірок надано 204 пропозиції з питань удосконалення протиепідемічної роботи.

\section{Висновки}

Встановлено спорадичний характер захворюваності на інфекційні хвороби населення, яке обслуговується 303 ДУС. Зареєстровано зниження показника захворюваності населення за 10 (40,0\%) нозологіями, з найвищим рівнем зниження показника за наступними нозологіями: краснуха $(16,86)$, скарлатина $(13,49)$, кашлюк $(8,43)$, харчова токсикоінфекція $(7,37)$. Підвищення показника захворюваності населення зареєстровано за 15 (60,0\%) нозологіями, з найвищими рівнями зниження показника за нозологіями: гострі респіраторні вірусні інфекції $(6833,45)$, грип $(230,83)$, вітряна віспа $(83,02)$, ангіна $(46,08)$. Робота епідеміологічного відділу санітарно-епідеміологічної станції ДУс була спрямована на проведення заходів з профілактики інфекційної захворюваності.

Перспективи подальших досліджень пов'язані з вивченням ефективності протиепідемічних заходів, які проводяться СЕС Державного управління справами.

\section{Список літератури}

1. Доклад о состоянии здравоохранения в мире 2000 г. Системы здравоохранения: улучшение деятельности. ВО3, 2000. - 232 c.

2. Европейская база данных «Здоровье для всех» [Электронный ресурс]. - Режим доступа : http://www.euro.who.int/ hfadb?language=Russian. - Название с экрана.

3. Здоровье-2020. Основы политики и стратегия / Шестьдесят вторая сессия, Европейский региональный комитет EUR/RC62/8, Мальта, 10-13 сентября 2012 г. Док. EUR/RC62/Conf.Doc./8. - EPK BO3, 2011. - 192 c.

4. Москаленко В. Ф. Здоровье и здравоохранение: ключевые императивы / В. Ф. Москаленко. - К. : ИД «Авиценна», 2011. - 256 с.

5. Охорона здоров'я України: стан, проблеми, перспективи / Лазоришинець В. В., Ковальчук Л. Я., Слабкий Г. О. [та ін.]. - К., 2014.- 608 с.

6. Щорічна доповідь про стан здоров'я населення, санітарно-епідемічну ситуацію та результати діяльності системи охорони здоров'я України. 2013 рік / за ред. О. С. Мусія. - К., 2014.- 438 с.

\section{К ВОПРОСУ ЗАБОЛЕВАЕМОСТИ ИНФЕКЦИОННЫМИ БОЛЕЗНЯМИ ОТДЕЛЬНОГО КОНТИНГЕНТА НАСЕЛЕНИЯ, КОТОРОЕ ОБСЛУЖИВАЕТСЯ МЕДИЦИНСКИМИ УЧРЕЖДЕНИЯМИ ГОСУДАРСТВЕННОГО УПРАВЛЕНИЯ ДЕЛАМИ}

Л.В. Крохмалюк

ГУ «Украинский институт стратегических исследований МЗ Украины», г. Киев

Санитарно-эпидемиологическая станция Государственного управления делами, г. Киев, Украина

Цель: изучить и проанализировать динамику заболеваемости инфекционными заболеваниями отдельного контингента населения, которое обслуживается в учреждениях здравоохранения Государственного управления делами (ГУД).

Материалы и методы. В ходе работы использован статистический метод исследования. Статистической обработке подлежали формы статистической отчетности за 2012-2013 гг.

Результаты. За исследуемый период установлено снижение показателя заболеваемости по следующим нозологиям: краснуха $(16,86)$, скарлатина $(13,49)$, коклюш $(8,43)$, пищевая токсикоинфекция $(7,37)$; и 
повышение показателя заболеваемости по следующим нозологиям: острые респираторные вирусные инфекции $(6833,45)$, грипп $(230,83)$, ветряная оспа $(83,02)$, ангина $(46,08)$.

Выводы. Установлен спорадический характер заболеваемости инфекционными болезнями населения, которое обслуживается УЗ ГУД. Работа санитарно-эпидемиологической станции была направлена на проведение профилактических мероприятий относительно инфекционной заболеваемости специального контингента населения.

КЛЮЧЕВЫЕ СЛОВА: инфекциооные болезни, заболеваемость, специальный контингент населения, Государственное управление делами.

\section{INCIDENCE OF INFECTIOUS DISEASES OF SEPARATE CONTINGENT OF THE POPULATION SERVED BY MEDICAL INSTITUTIONS OF THE STATE ADMINISTRATION AFFAIRS}

\section{L.V. Krohmaljuk}

PE "Ukrainian Institute of Strategic Researches MHC of Ukraine", Kyiv

Sanitary-and-epidemiologic station of the State Administration Affairs, Kyiv, Ukraine

Purpose: to study and analyze dynamics of the incidence of infectious diseases of separate contingent of served population in health care institutions of the State Administration Affairs (SAA).

Materials and methods. During work performance, the statistical method of research has been used. Forms of the statistical reporting for 2012-2013 years were subject to statistical processing.

Results. For the investigated period decrease in an indicator of disease on the following nosology has been established: rubella $(16,86)$, scarlet fever $(13,49)$, pertussis $(8,43)$, food poisoning $(7,37)$; and increase of an indicator of disease on the following nosology: acute respiratory virus infections $(6833.45)$, influenza $(230,83)$, chicken pox $(83,02)$, angina $(46,08)$.

Conclusions. Sporadic character of incidence by infectious diseases of the population served by HCF SAA is established. The work of sanitary-and-epidemiologic station has been directed for carrying out of preventive measures for infectious disease of special contingent of the population. Affairs.

KEY WORDS: infectious diseases, morbidity, special contingent of the population, State Administration

Відомості про автора:

Рукопис надійшов до редакції 07.11.2014 р.

Крохмалюк Любомир Валерійович - головний лікар Санітарно-епідеміологічної станції Державного управління справами; тел. +38(044)526-51-11. 